\title{
Induction of superovulation in DD mice at different stages of the oestrous cycle
}

\author{
O. E. Redina, S. Ya. Amstislavsky and L. F. Maksimovsky \\ Institute of Cytology and Genetics of the Russian Academy of Sciences, Lavrentjeva 10, Novosibirsk-90, \\ Russia, 630090
}

\begin{abstract}
This study examined the developmental capacity of oocytes in DD mice after they had been injected with pregnant mares' serum gonadotrophin at different stages of the oestrous cycle. The superovulation of mature DD mice at pro-oestrus, oestrus and metoestrus resulted in a large yield of viable embryos. The proportion of abnormal embryos was highest after injection of pregnant mares' serum gonadotrophin at dioestrus. The pool of viable oocytes was most synchronized with normal development after the hormone was injected at oestrus. The results demonstrate that oocytes of different morphology could be induced to ovulate. The developmental capacity of oocytes of different morphology is discussed.
\end{abstract}

\section{Introduction}

Administration of exogenous gonadotrophins to female mammals causes superovulation, which is used as a routine procedure for producing greater yields of embryos in developmental and genetic studies. However, compared with spontaneous ovulation, superovulation is associated with a greater loss of embryos during pregnancy (Allen and McLaren, 1971; Beaumont and Smith, 1975; Miller and Armstrong, 1982; Walton et al., 1983).

The mechanisms by which gonadotrophins increase the incidence of abnormal ova are unclear, but some suggestions have been made. Degenerative changes occur in some ova as a result of fertilization failure (Walton et al., 1983; Evans and Armstrong, 1984), possibly owing to an imbalance in the concentrations of oestradiol and progesterone (Miller and Armstrong, 1981, 1982; Jutaro et al., 1982). Injections of pregnant mares' serum gonadotrophin (PMSG) result in the appearance of a number of cumulus-free oocytes. Any abnormality of cumulus-free oocytes could result from ageing, as they had presumably ovulated in response to LH present in the injected PMSG (Murphy et al., 1984). These prematurely ovulated eggs would be too old to be fertilized (Gates, 1971). Moreover, it has been shown that treatment with gonadotrophins produces genetic defects in the ova in vivo (Luckett and Mukherjee, 1986) and in vitro (Maudlin and Frazer, 1977).

However, the incidence of atresia among antral follicles is significantly reduced after injection of PMSG. Two hypotheses have been suggested: PMSG either prevents some normal follicles becoming atretic or it rescues some atretic follicles so that they revert to a normal state (Peters et al., 1975; Braw and Tsafriri, 1980; Moniaux et al., 1984).

Although little is known about the mechanisms that produce abnormal ova, attempts have been made to find methods to decrease the embryonic loss. It was found that administration of gonadotrophins i.p. increases the proportion of abnormal

Received 10 February 1994. ova more than if they are administered s.c. (Lehtonen and Kankondi, 1987). Attempts were made to synchronize the administration of gonadotrophins with the innate oestrous cycle by timing the administration of hCG to coincide with the endogenous LH surge, but these attempts did not result in better embryo survival (Beaumont and Smith, 1975).

Farm animals are induced to superovulate at a known stage of their oestrous cycle to maximize superovulation yields (Sreenan and Gosling, 1977; Rajamahendran et al., 1987) but in routine laboratory studies randomly selected mice are used.

The present study was undertaken to determine the most favourable stage of the mouse oestrous cycle for obtaining the highest number of viable embryos after PMSG or hCG treatment. The developmental capacity of oocytes after injection of PMSG at different stages of the oestrous cycle was examined. It was shown that in DD mice the proportion of abnormal embryos was highest after PMSG injection at dioestrus. PMSG injection at pro-oestrus, oestrus and metoestrus resulted in a large yield of viable embryos; the greatest number of viable oocytes synchronized with normal development was found after PMSG injection at oestrus.

\section{Materials and Methods}

\section{Animals}

Mature females (8-10 weeks old) of the inbred DD/HeIcgn (DD), C57BL/6JYlcgn and CBA/CaLaclcgn (CBA) strains and outbred ICR mice were tested to find a strain with a high PMSG-induced ovulation rate. Mice were kept in small groups (4-6 mice in one cage) under the natural photoperiod (during the study, the light period was from about 08:00 $\mathrm{h}$ to $20: 00 \mathrm{~h}$ ).

\section{Stages of the oestrous cycle}

Vaginal smears of DD mice were taken daily for 10 days to establish the pattern of the oestrous cycle for each animal 
before PMSG administration. Vaginal smears were taken by spatular sampling from the mucosa of vaginal walls between 12:00 h and 13:00 h. The stages of the cycle were classified as follows: oestrus, cornified cells only; metoestrus, comified cells and leucocytes; dioestrus, leucocytes and mucous cells; pro-oestrus, nucleated cells or nucleated cells and cornified cells.

\section{Induction of superovulation}

DD females were given an injection of 10 iu PMSG (Pokrovsky Plant of Biopreparations, Pokrovsky) s.c. at 15:00 h and 10 iu hCG (Moscow Plant of Endocrine Preparations, Moscow) $48 \mathrm{~h}$ later to induce superovulation. The doses had been determined as optimal in a separate study (Amstislavsky et al., 1991).

\section{Experimental procedure}

Treated females were individually caged overnight with males of the same strain and were examined for vaginal plugs on the next morning. The superovulated oocytes were analysed from females that were kept with a male but did not mate. Oocytes were recovered 20-22 h after hCG injection by dissecting the oviducts in medium 199 (Scientific Institute of Viral Infections, Sverdlovsk). Oocytes were characterized as cumulus-enclosed or cumulus-free. Hyaluronidase (Reanal, Budapest) was used to remove cumulus cells (Brinster, 1971). Females with vaginal plugs were analysed on day 3 of pregnancy (the day on which a vaginal plug was found was designated as day 1). Each oviduct was separated from the uterine horn at the uterotubal junction and then flushed with medium 199. Material flushed from the tubes was examined under an inverted Wild Leitz microscope $(\times 120)$. Oocytes (and embryos on day 3) were counted and classified according to their stage of development. Oocytes recovered from unmated females were evaluated as fragmented, without a polar body, with a forming polar body (pear-shaped oocytes) and with a formed polar body. Embryos were considered to be normal if they had four or more blastomeres. Two-cell ova found on day 3 were considered as having arrested cleavage. Fragmented, degenerated and cleavage-arrested ova were considered abnormal. Untreated females with spontaneous ovulation were used as controls.

\section{Statistical analyses}

Analysis of variance by ANOVA was used to test the effect of the stage of the oestrous cycle on the number of oocytes and 3-day-old embryos of different morphology. The developmental capacity of 3-day-old embryos after PMSG injection at different stages of the oestrous cycle was compared with analysis of Fourfold Tables (stages were tested in pairs).

\section{Results}

DD and ICR mice had 4-7 times more embryos after superovulation than did C57BL/6JYIcgn and CBA mice. DD mice
Table 1. Embryo development after PMSG-induced ovulation in mature mice of different strains

\begin{tabular}{lccc}
\hline Strain of mice & $\begin{array}{c}\text { Number of } \\
\text { animals }\end{array}$ & $\begin{array}{c}\text { Number of } \\
\text { embryos }\end{array}$ & $\begin{array}{c}\text { Percentage } \\
\text { of embryos } \\
\text { with normal } \\
\text { development }\end{array}$ \\
\hline DD & 78 & $42.0 \pm 1.5$ & 68.2 \\
ICR & 11 & $26.4 \pm 3.3$ & 52.2 \\
C57BL/6JYIcgn & 14 & $7.9 \pm 1.0$ & 73.0 \\
CBA & 21 & $5.5 \pm 1.2$ & 85.0 \\
\hline
\end{tabular}

Values are means \pm SEM.

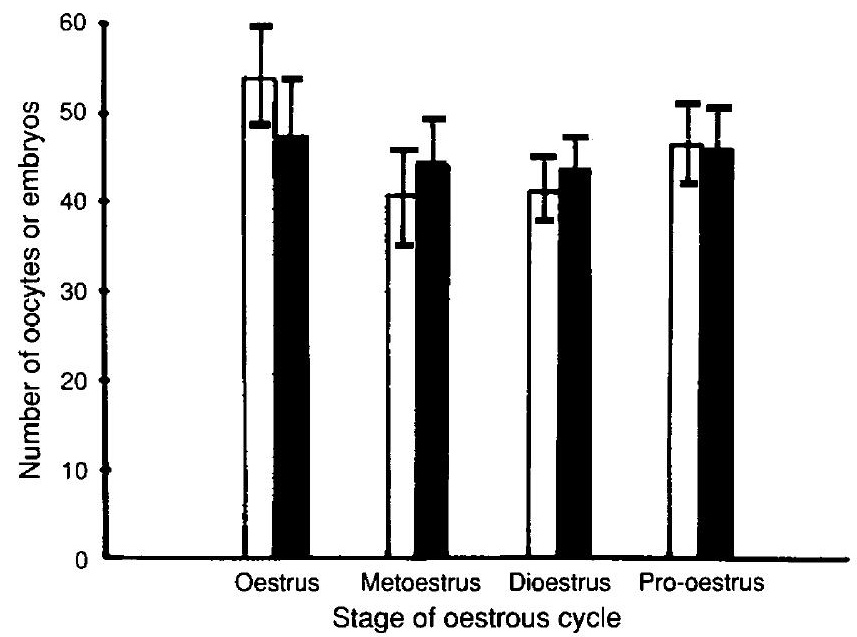

Fig. 1. The total number of oocytes $(\square)$ and 3-day-old embryos ( $\square$ ) obtained from DD mice after injection of pregnant mares' serum gonadotrophin at different stages of the oestrous cycle.

were the most sensitive to PMSG treatment (Table 1); this strain was therefore used during the remainder of the study.

DD females were administered gonadotrophins at different stages of the oestrous cycle (pro-oestrus, oestrus, metoestrus and dioestrus). The PMSG-induced ovulation rate was high at all stages tested. The total number of oocytes was greatest after injection of PMSG at oestrus; the total number of superovulated embryos on day 3 did not differ significantly within the oestrous cycle (Fig. I).

Two groups of oocytes (cumulus-free and cumulus-enclosed) were obtained after PMSG injection at all stages of the oestrous cycle. All cumulus-free oocytes were fragmented while the morphology of the cumulus-enclosed oocytes was different (Table 2). Nearly all spontaneously ovulated oocytes in untreated females had a formed polar body. The pool of viable oocytes was most synchronized with normal development after PMSG injection at oestrus. The stage of the oestrous cycle significantly $(P<0.05)$ affected the number of oocytes with a formed polar body. No effects of the stage of the oestrous cycle on the number of fragmented cumulus-free oocytes, cumulus-enclosed abnormal oocytes, oocytes without a polar body or oocytes with a forming polar body were found. 
Table 2. The morphology of ovulated oocytes in DD mice induced to superovulate at different stages of the oestrous cycle

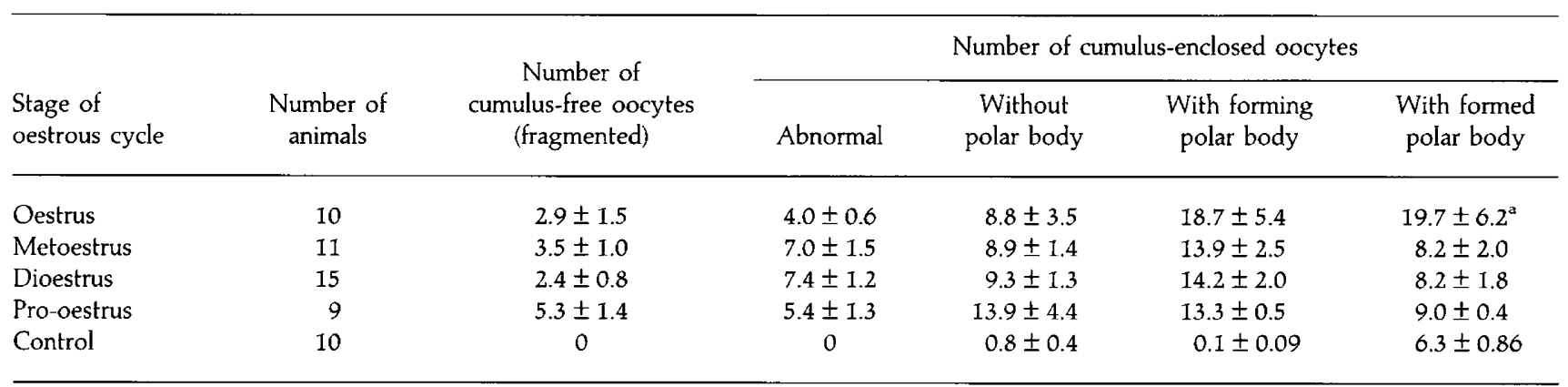

Values are means \pm seM.

${ }^{a}$ The stage of the oestrous cycle significantly $(F=3.03 ; P<0.05)$ affected the number of oocytes with a formed polar body.

Table 3. The development of 3-day-old embryos in DD mice induced to superovulate at different stages of the oestrous cycle

\begin{tabular}{lcccc}
\hline $\begin{array}{l}\text { Stage of } \\
\text { oestrous cycle }\end{array}$ & $\begin{array}{c}\text { Number of } \\
\text { females }\end{array}$ & $\begin{array}{c}\text { Number of } \\
\text { normal embryos }\end{array}$ & $\begin{array}{c}\text { Number of } \\
\text { abnormal embryos }\end{array}$ & $\begin{array}{c}\text { Proportion of } \\
\text { abnormal embryos }\end{array}$ \\
\hline Oestrus & 7 & $35.7 \pm 8.5$ & $14.3 \pm 2.2$ & $0.28 \pm 0.06$ \\
Metoestrus & 8 & $32.6 \pm 3.9$ & $11.0 \pm 1.0$ & $0.27 \pm 0.05$ \\
Dioestrus & 10 & $23.0 \pm 2.2$ & $21.0 \pm 2.8^{\text {a }}$ & $0.47 \pm 0.05$ \\
Pro-oestrus & 7 & $32.5 \pm 3.6$ & $13.2 \pm 2.3$ & $0.28 \pm 0.06$ \\
\hline
\end{tabular}

Values are means \pm SEM.

aThe stages of the oestrous cycle significantly $(F=3.96 ; P<0.05)$ affected the number of embryos with abnormal development.

The proportion of viable embryos was higher after PMSG injection at pro-oestrus, oestrus and metoestrus compared with dioestrus (Table 3). Analysis of Fourfold Tables showed significant $(P<0.001)$ differences between the ratios of normal: abnormal 3-day-old embryos in pairs: oestrus-dioestrus; metoestrus-dioestrus and pro-oestrus-dioestrus. Comparisons between oestrus, metoestrus and pro-oestrus showed no differences in the ratios of normal:abnormal embryos. Analysis of variance by ANOVA showed that the stage of the oestrous cycle significantly $(P<0.05)$ affected the number of abnormal embryos.

\section{Discussion}

The different strains of 8-10-week-old mice produced different numbers of embryos following PMSG/hCG treatment. DD and ICR mice showed high superovulation yields, while C57BL/6 JYlcgn and CBA mice showed low superovulation yields. These differences may be due to different concentrations of endogenous hormones in females (Goto et al., 1987) or to a different responsiveness of the ovaries to exogenous gonadotrophins (Spearow, 1988a, b), which could influence the number of eggs superovulated.

In agreement with previous studies (Edwards et al., 1963) we noted that the total number of superovulated oocytes and embryos on day 3 did not vary significantly during the cycle. It is known that preantral follicles that can mature $(100-149 \mu \mathrm{m}$ in diameter) grow faster than any other follicles
(Numazawa and Kawashima, 1982). Their growth rate is not significantly influenced by the stage in the oestrous cycle (Pedersen, 1970). Presumably, the total number of these competent follicles present in the ovary of the treated females could determine the total number of eggs superovulated.

Two groups of oocytes (cumulus-free and cumulus-enclosed) were present after PMSG injection at all stages of the oestrous cycle in DD mice. Fragmented, cumulus-free oocytes could result from ageing, as they had presumably been ovulated because of an LH-like effect of PMSG (Gates, 1971). Fully developed follicles are present in late pro-oestrus in mouse and rat ovaries (Pedersen, 1970; Richards, 1978), which may explain why we observed a higher proportion of cumulus-free oocytes after an injection of PMSG during pro-oestrus.

The different morphology of cumulus-enclosed oocytes showed that oocytes at different developmental stages (i.e. at different ages) could be induced to ovulate. The age of an oocyte is known to be of great importance for its developmental capacity (Martin and Terranova, 1982). The ageing of oocytes leads to a decreased fertilization rate (Evans and Armstrong, 1984), to an increased incidence of polyspermy (Odor and Blandau, 1956), to changes in some organelles (Bedford, 1971) and to a decreased RNA concentration in oocytes (Bogomolova et al., 1981). Thus, the different developmental stages (different ages) of superovulated oocytes could explain the difference in their developmental capacity. Under normal conditions the extrusion of the first polar body in the mouse occurs before the egg is released from the follicle (Bedford, 1971; Hogan et al., 1986). The oocytes with a formed 
polar body therefore ovulated before they were too old. The best developmental capacity might thus be expected among the pool of oocytes that ovulated with a formed polar body, as these are synchronized with normal development. The highest proportion of oocytes of this type was found after PMSG injection at oestrus.

The developmental capacity of oocytes depends upon the size of the follicles from which the oocytes were isolated, but not strictly upon the size of the oocyte (Eppig et al., 1992). Eppig and Schroeder (1989) showed that oocytes from preantral follicles of mice can complete growth and acquire full developmental competence in vitro. So we could expect normal development of oocytes of different morphology. To estimate the developmental capacity of oocytes of different morphology, the number of ovulated oocytes and the number of viable embryos on day 3 were compared (Tables 2,3). These data suggest that normal development occurs not only in oocytes with a formed polar body but also in oocytes with a forming polar body and those without a polar body. The oocytes with a forming polar body do not seem to be too old to be viable.

There are two possible explanations of how oocytes without a polar body may develop normally. First, in rats, and often in mice, the first polar body disappears soon after its extrusion (Bedford, 1971). The development of oocytes without a polar body could be ahead of that of others, and such oocytes may have lost their polar body before their morphology was assessed. Second, the oocyte is released from the follicles 11-13 h after hCG injection in gonadotrophin-treated mice (Gates, 1971); that is, competent oocytes ovulate 59-61 h after PMSG injection. However, under normal conditions preantral follicles develop to ovulating follicles within two cycles (Numazawa and Kawashima, 1982). Hence, it is possible that not all oocytes have time to complete the first meiotic division before ovulation, and that some oocytes without a polar body could have a chance to complete the first meiotic division in the ampulla of the Fallopian tube and to be fertilized later than others.

Superovulation yielded a significantly higher proportion of viable embryos after PMSG injection at pro-oestrus, metoestrus and oestrus compared with PMSG injection at dioestrus. After PMSG injection at dioestrus, $47.7 \%$ of 3-dayold embryos were abnormal, which is in agreement with the result of Beaumont and Smith (1975), who found that $44 \%$ of ova were lost before implantation after inducing superovulation with exogenous PMSG at dioestrus. In rodents, the pool of committed growing follicles is greatest at oestrus as a result of the pro-oestrus surge of endogenous FSH (Pedersen, 1970; Richards, 1978). It seems that synchronizing PMSG treatment with such an endogenous hormonal event does provide optimal conditions for the development of superovulated oocytes.

This work was supported in part by a grant from the Russian State Program 'Frontiers in Genetics'.

\section{References}

Allen J and McLaren A (1971) Cleavage rate of mouse eggs from induced and spontaneous ovulation Journal of Reproduction and Fertility 27 137-140
Amstislavsky SYa, Faizullin RZ, Golubitsa AN, Zhelezova AI, Maksimovsky LF and Manziuk AV (1991) PMSG-induced superovulation in different strains of mice Siberian Journal of Biology $627-31$

Beaumont HM and Smith AF (1975) Embryonic mortality during the pre- and post-implantation periods of pregnancy in mature mice after superovulation Journal of Reproduction and Fertility 45 437-448

Bedford JM (1971) Techniques and criteria used in the study of fertilization. In Methods in Mammalian Embryology pp 37-63 Ed. IC Daniel. Freeman, San Francisco

Bogomolova VI, Golubitsa AN, Zhelezova Al, Maksimovsky LF, Pashinin YuV, Poznakhirkina NA, Chugaeva LA and Korochkin LI (1981) A study of embryonic development in two mouse strains during early cleavage Ontogenes 12 610-616 (in Russian)

Braw RH and Tsafriri A (1980) Effect of PMSG on follicular atresia in the immature rat ovary Journal of Reproduction and Fertility 59 267-272

Brinster RL (1971) Measuring embryonic enzyme activity. In Methods in Mammalian Embryology pp 215-227 Ed. JC Daniel. Freeman, San Francisco

Edwards RG, Wilson ED and Fowler RE (1963) Genetic and hormonal influences on ovulation and implantation in adult mice treated with gonadotrophins Journal of Endocrinology 26 389-399

Eppig JJ and Schroeder AC (1989) Capacity of mouse oocytes from preantral follicles to undergo embryogenesis and development to live young after growth, maturation and fertilization in vitro Biology of Reproduction $\mathbf{4 1}$ $268-276$

Eppig JJ, Schroeder AC and O'Brien MJ (1992) Developmental capacity of mouse oocytes matured in vitro: effect of gonadotrophic stimulation, follicular origin and oocyte size Journal of Reproduction and Fertility 95 119-127

Evans $G$ and Amstrong DT (1984) Reduction in fertilization rate in vitro of oocytes from immature rats induced to superovulate Journal of Reproduction and Fertility 70 131-135

Gates AH (1971) Maximizing yield and developmental uniformity of eggs. In Methods in Mammalian Embryology pp 64-75 Ed. JC Daniel. Freeman, San Francisco

Goto K, Nakanishi Y and Ohkutsu S (1987) Plasma progesterone profiles and embryo quality in superovulated black cattle Theriogenology 27 819-826

Hogan B, Costantini F and Lacy E (1986) Manipulating the Mouse Embryo: a Laboratory Manual. Cold Spring Harbor Laboratory Press, New York

Jutaro T, Kazumasa $H$ and Junji M (1982) Disturbance of pregnancy and the serum prolactin and progesterone levels in superovulated adult rats Japanese Journal of Animal Reproduction 28 59-66

Lehtonen E and Kankondi R (1987) Rate of gonadotrophin-induced abnormalities in mouse ova is related to the site of hormone administration Journal of Reproduction and Fertility $80613-617$

Luckett DC and Mukherjee AB (1986) Embryonic characteristics in superovulated mouse strains Journal of Heredity 77 39-42

Martin NC and Terranova PF (1982) Effects of delayed ovulation on pregnancy in the PMSG-treated immature rat Proceedings of the Society for Experimental Biology and Medicine 169 226-232

Maudlin I and Frazer LR (1977) The effect of PMSG dose on the incidence of chromosome anomalies in mouse embryos fertilized in vitro Journal of Reproduction and Fertility $50275-280$

Miller BG and Armstrong DT (1981) Effect of superovulatory dose of pregnant mares' serum gonadotrophin on ovarian function, serum estradiol and progesterone levels and early embryo development in immature rats Biology of Reproduction 25 261-271

Miller BG and Armstrong DT (1982) Infertility in superovulated immature rats: role of ovarian steroid hypersecretion Biology of Reproduction 26 861-868

Monniaux D, Mariana JC and Gibson WR (1984) Action of PMSG on follicular population in the heifer Journal of Reproduction and Fertility 70 243-253

Murphy BD, Mapletoft RG, Manns J and Humphrey WD (1984) Variability in gonadotrophin preparations as a factor in the superovulatory response Theriogenology 21 117-122

Numazawa A and Kawashima S (1982) Morphometric studies on ovarian follicles and corpora lutea during the oestrous cycle in the mouse Journal of Reproduction and Fertility $64275-283$

Odor L and Blandau RG (1956) Incidence of polyspermy in normal and delayed matings in rats of the Wistar strain Fertility and Sterility $7456-467$

Pedersen $T$ (1970) Follicle kinetics in the ovary of the cyclic mouse Acta Endocrinologica 64 304-323

Peters H, Byskov AG, Himelstein-Braw R and Faber M (1975) Follicular growth: the basic event in the mouse and human ovary fournal of Reproduction and Fertility 45 559-566 
Rajamahendran R, Conseco RS, Denbow C, Gwazdauskau FC and Vinston WE (1987) Effects of low dose of FSH at the beginning of the estrous cycle and subsequent superovulatory response in Holstein cows Theriogenology 28 $59-65$

Richards JS (1978) Hormonal control of follicular growth and maturation in mammals. In The Vertebrate Ovary pp 331-360 Ed. EJ Richard. Plenum Press, New York and London

Spearow JL (1988a) Major genes control hormone-induced ovulation rate in mice Journal of Reproduction and Fertility 82 787-797
Spearow JL (1988b) Characterization of genetic differences in hormonalinduced ovulation in mice Journal of Reproduction and Fertility $\mathbf{8 2}$ 799-806

Sreenan JM and Golling IJ (1977) The effect of stage and plasma progesterone level on the induction of multiple ovulation in heifers Journal of Reproduction and Fertility 50 367-369

Walton EA, Evans G and Armstrong DT (1983) Ovulation response and fertilization failure in immature rats induced to superovulate Journal of Reproduction and Fertility 67 91-96 